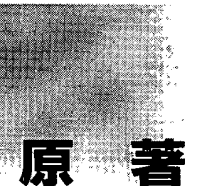

論文受付

2003年 3 月 5 日

2003年 ${ }^{\text {論文受理 }}$

Code Nos. 431

524

534

\section{放射線治療に扣けるポータルイメージの 白動照合プログラムの開発}

\author{
赤澤博之・中森伸行 ${ }^{1)} \cdot$ 塩本敦子 2 - 矢野慎輔 $\left.{ }^{2}\right) \cdot$ 岡田 \\ 小川憲—2) · 小松龍一2) · 森本美穂2) $\cdot$ 高倉 亨2) \\ 永田 靖3) - 平岡畺宽 ${ }^{3)}$ \\ 京都大学医学部附属病院放射線部 \\ （現 京都医療技術短期大学診療放射線技術学科） \\ 1) 京都工芸紼維大学工芸学部電子情報工学科 \\ 2)京都大学医学部附属病院放射線部 \\ 3) 京都大学大学院医学研究科放射線医学講座腫瘍放射線科学
}

\section{緒 言}

放射線治療の目的は，病巣周囲の正常組織に対する 障害を可能な限り少なくし, 臨床標的体積に対して計 画した線量を正確に，かつ高い位置精度で照射するこ とである。しかしながら, 高エネルギーX線を用いた 外部照射では, 位置決めから実際の照射にいたる過程 で，さまざまな機械的誤差と人為的誤差が入り込む. これらの誤差を減らし, 高い位置精度で外部照射を行 うためには，正確な照射野照合が必要である1). 照射 野照合の方法としては, 従来からX線フィルムを用い
た写真照合が主流であり, 最近ではelectronic portal imaging devices (EPID) も臨床で使用されるようにな ってきた。しかし，どちらの場合でも目視による照射 野照合のため, 観察者の主観や経験などで差が生じた り，ときには誤りが起こった。

わが国でも過去に，照合写真による照射位置の再現 性に関する報告2 4)があるが，臨床では目視による評 価が主流であり，客観的な照射野照合の手法について の報告はない.

本研究では，シミュレーションイメージとポータル

\title{
Development of Automatic Verification System for Portal Image in Radiotherapy
}

\section{HIROYUKI AKAZAWA, NOBUYUKI NAKAMORI, 1) ATSUKO SHIOMOTO, 2) SHINSUKE YANO, ${ }^{2)}$ TAKASHI OKADA, 2) KENICHI OGAWA, 2) RYUUICHI KOMATSU, ${ }^{2)}$ MIHO MORIMOTO, ${ }^{2)}$ TOORU TAKAKURA, ${ }^{2)}$ YASUSHI NAGATA, ${ }^{3)}$ and MASAHIRO HIRAOKA ${ }^{3)}$}

Clinical Radiology Service, Kyoto University Hospital

(Present address: Department of Radiological Technology, Kyoto College of Medical Technology)

1) Department of Electronics and Information Science, Kyoto Institute of Technology

2) Clinical Radiology Service, Kyoto University Hospital

3)Department of Therapeutic Radiology and Oncology, Kyoto University, Graduate School of Medicine

Received March 5, 2003; Revision accepted Sept. 24, 2003; Code Nos. 431, 524, 534

\section{Strmary}

The current method of verification for external beam radiation therapy visually compares a simulation image with a portal image. However, because this method depends largely upon the observer's experience, it sometimes results in inter-observer differences. In this study, we developed software to measure atomatically the quantitative difference between the simulation image and portal image using an image-analysis method. The feasibility of this software was evaluated on a rectangular field in the pelvic region. We took 12 simulation images of a pelvic phantom, setting 4 different field shapes on each of 3 isocenters. We then obtained 84 portal images setting 7 known distances from each of the 12 simulation images. Using this software, the direction of shift was detected correctly, and the distance of shift was detected correctly to within less than 3 $\mathrm{mm}$. We consider that this software could be a useful method of verification.

\section{Key words: Automated verification, Simulation image, Portal image, Pelvic region, Image processing}




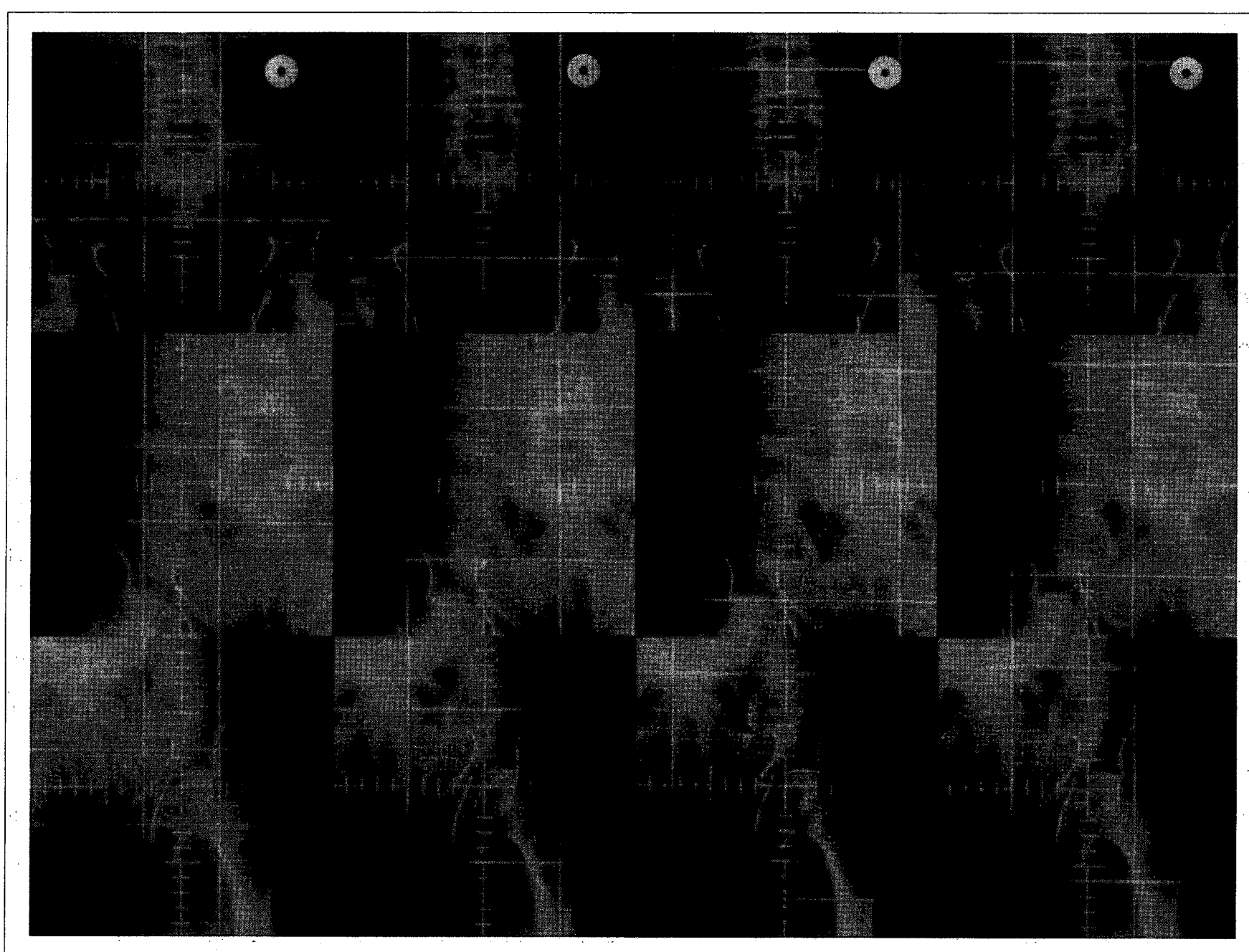

Fig. 1 All simulation images.

Top to bottom: the isocenter is located in the central part of the sacrum, the iliac bone, and the hip joint. Left to right: field shape is $5 \mathrm{~cm}$ sq., $10 \mathrm{~cm}$ sq., $15 \mathrm{~cm}$ sq., and $14 \times 8 \mathrm{~cm}$ (asymmetrical).

イメージの間の照射野のズレを, コンピュータを用い た画像解析で定量的に検出する方法を開発し, 骨盤領 域の矩形照射野を対象としてその有用性を調べた。ま た観察者の判断を介在させずに，つまり個々の画像に 応じた人為的なパラメータを入力せずに検出可能であ るかを検討した。

\section{1. 便用機器および対象}

\section{1-1 使用機器}

X線位置決め装置 : Ximatron(Varian)

診療用高エネルギー放射線発生装置: Clinac2300C/D (Varian)

骨盤部人体ファントム：PBU-10 (京都科学)

プルムスキャナ：VXR-12 X-ray Film Scanner (Vidar)

コンピュータ：Windows2000(Microsoft)ベースのパ

ーソナルコンピュータ

プログラム開発環境：Visual C++ Ver6.0(Microsoft)

\section{1-2 対象}

骨盤部人体ファントムを用い, シミュレーションイ メージはアイソセンタ 3 種類 (Fig. 1 上段から仙骨中央 部, 腸骨部, 股関節部)について, それぞれ照射野サ イズ 4 種類 (Fig. 1左列から $5 \mathrm{~cm} \times 5 \mathrm{~cm}, 10 \mathrm{~cm} \times 10 \mathrm{~cm}$, $15 \mathrm{~cm} \times 15 \mathrm{~cm}$, 頭尾方向 $14 \mathrm{~cm}$ 非対称 $\times$ 左右方向 $8 \mathrm{~cm}$ 非 対称)を撮影した(計12枚).

各シミュレーションイメージに対して，そのアイソ セン夕を既知量 $(\mathrm{A}$ ：シミュレージョシイメージのア イソセンタ通り, B：シミュレーションイメージのア イソセンタより頭側へ $5.0 \mathrm{~mm}, \mathrm{C}$ : 同尾側へ $10.0 \mathrm{~mm}$, $\mathrm{D}$ ：同向かって左側へ $5.0 \mathrm{~mm}, \mathrm{E}$ ：同向かって右側へ $10.0 \mathrm{~mm} ; \mathrm{F}:$ 同尾側へ $5.0 \mathrm{~mm}$ 向かって右側へ $5.0 \mathrm{~mm}$, $\mathrm{G}$ ：同頭側へ $10.0 \mathrm{~mm}$ 向かって左側へ $10.0 \mathrm{~mm})$ 偏移さ せたポータルイメージを 7 種類撮影した(計84枚).

上記シミュレーションイメージとポータルイメージ 計84対について, 提案した手法を用いたズレの検出結 果と先に示した既知のズレ量とを比較した。 


\section{2. 方 法}

\section{2-1 画像処理の概略}

処理の概略をFig. 2に示す。まずX線フィルムで取得 したシミュレーションイメージとポータルイメージを フィルムスキャナによりディジタル化し, 両画像上で 共通の基準点となる照射野の中心とその 4 隅の座標 (Fig. 3の黒印で示した位置)を検出する。これらの基 準点から両画像の拡大率とフィルム上の照射野位置の 違いを算出し, 一方の画像を拡大, 移動(線形補間) し て両画像の照射野を一致させた。また照射野サイズを 入力して，画素サイズを $\mathrm{X}, \mathrm{Y}$ 方向について独立に求 めた。次に，両画像に対してコントラスト強調処理 (ヒストグラムの平坦化)を行い, 撮影条件とくにX線 エネルギーの違いに起因するコントラスト不良を改善 した.この画像に対してスムージング処理(平滑化フ イルタ), エッジ強調処理(ラプラシアンフィルタ), 2 值化処理 (パーセンタイル法)を順次行い, 骨陰影な どの比較対照となる構造を抽出した。 以上の処理で得 た 2 枚の画像間のズレの方向および大きさを，二次元 の相互相関関数を計算して求めた ${ }^{5,6)}$.

\section{2-2 X線フィルムのディジタル化}

X線フィルムとして取得したシミュレーションイメ ージおよびポータルイメージをフィルムスキャナで縦 (Y方向)256画素 $\times$ 横 (X方向)256画素, グレースケール 256階調でディジタル化した，その範囲は各画像の照 射野辺縁から 2 $8 \mathrm{~cm}$ 程度外側まで含んだ領域で，画 素サイズは各画像により異なっている.

Fig. 3にシミュレーションイメージとポータルイメ ージの原画像の一例を示す。同じ被写体であるが撮影 条件，特にX線エネルギーが違うため，両画像のコン トラストは大きく異なる.

シミュレーションイメージの撮影条件は，管電圧

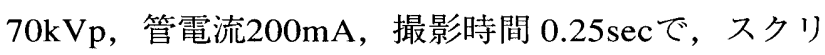
ーンフィルムシステムはNewA (Konica) /HS-V250 （KYOKKO）を用いた。またポータルイメージの撮影 条件は，X線エネルギー $6 \mathrm{MV}$ ，照射線量約 $3 \mathrm{cGy}$ (才 一プン)+約 $2 \mathrm{cGy}$ (照射野サイズ)で，スクリーンフィ ルムシステムはEC-L (Kodak)を用いた。現像条件は同 じで，現像温度 $35^{\circ} \mathrm{C}$ ，処理時間 $90 \mathrm{sec}$, プロセッサは 5000RA Processor (Kodak)，処理液はICM-D1／ICMF(Kodak)を用いた。

\section{2-3 基準点の検出}

シミュレーションイメージとポータルイメージでは 撮影時の幾何学的配置が異なるため, 焦点一フィルム 間距離の違いが像の大きさ (拡大率)に，線束に直交す る面内でのフィルムを置く位置がフィルム上での像の

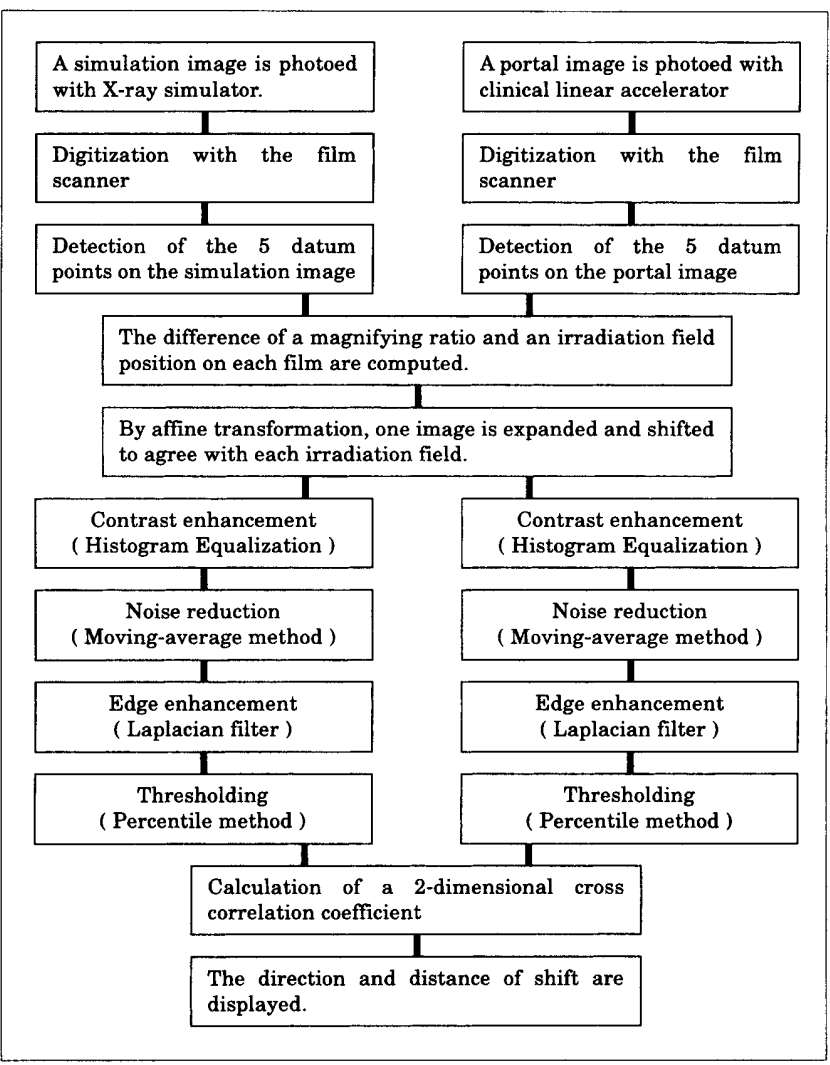

Fig. 2 Overall schema of image-processing technique.

位置に，それぞれ影響を及ぼす。これを補正するため に両画像で共通の基準点となる照射野の中心抢よびそ の 4 隅の座標 (Fig. 3の黒印で示した位置)を検出し た。処理手順を以下に示す.

(1)原画像に対して，X方向およびY方向に独立して， 1 ラインごとの平均画素值を計算する (Fig. 4d, 5d).

(2)X方向およびY方向の平均画素值を 1 次微分する. オペレータの係数は $\{-1,0 ， 1\}$ を用いた。

(3)シミュレーションイメージ(Fig. 4b，c)では，微分 操作でワイヤーの陰影の両側にピークが現れる. 各基準点の座標はこれらの中心とした：ポータル イメージ(Fig. 5b，c）の照射野中心についても同様 である。これよりX方向およびY方向それぞれ 3 点 の座標が得られ，これらが照射野の上下縁または 左右緣と中心に対応する。

以上より五つの基準点の座標が求まった.

\section{2-4 拡大率とフィルム位置の補正}

前節で求めたシミュレーションイメージとポータル イメージの基準点の座標を比較し，ポータルイメージ に対するシミュレーションイメージの拡大率およびフ イルム上の照射野位置の違いを算出する.X方向およ びY方向の拡大率をそれぞれmag_x, mag_y, フィル ム上の照射野位置の違いをそれぞれshift_x, shift_yと 

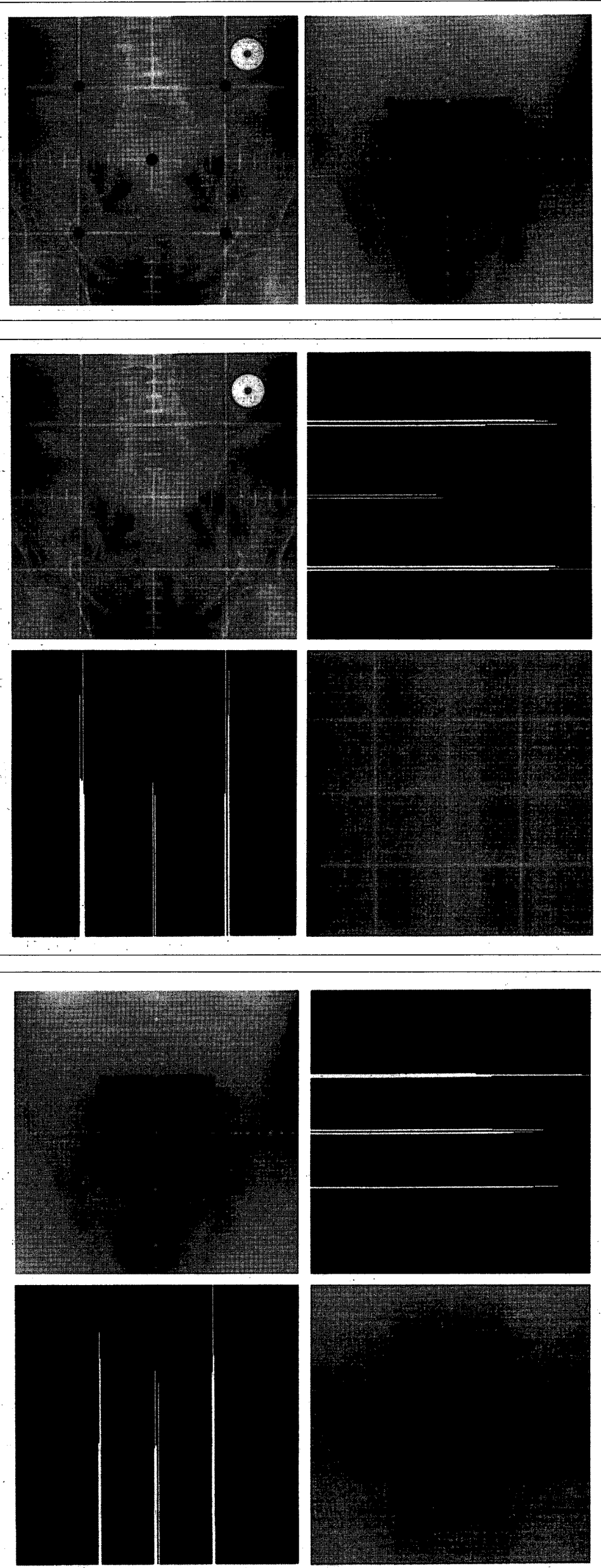

$a \mid b$

Fig. 3 Original simulation image and original portal image. The round marks in the figure show 5 datum points.

(a) Original simulation image.

(b) Original portal image.

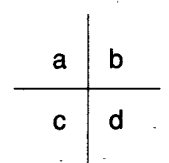

Fig. 4 Result of detection of datum points on a simulation image.

(a) Original image.

(b) Peaks detected from the profile of the $\mathrm{Y}$-direction.

(c) Peaks detected from the profile of the $X$-direction.

(d) Profile of mean pixel values of the $X$ and $Y$ directions.

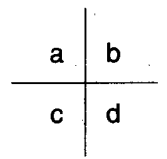

Fig. 5 Result of detection of datum points on a portal image.

(a) Original image.

(b) Peaks detected from the profile of the Y-direction.

(c) Peaks detected from the profile of the X-direction.

(d) Profile of mean pixel values of $X$ and $Y$ directions. 
すると, ポータルイメージ上の座標 (Portal_x, Portal_y)は，シミュレーションイメージ上の座標 （Sim_x，Sim_y）を用いて（1）式と表せる.

$\left(\begin{array}{l}\text { Portal_x } \\ \text { Portal_y }\end{array}\right)=\left(\begin{array}{cc}\text { mag_x } & 0 \\ 0 & \text { mag_y }\end{array}\right)\left(\begin{array}{l}\text { Sim_z }_{-} x \\ \text { Sim_z }_{-} y\end{array}\right)+\left(\begin{array}{l}\text { shift_x } \\ \text { shift_y }\end{array}\right)$

これらの值から両画像の画素サイズを同じにし，さ らに両画像の照射野を重ね合わせることで，骨陰影な どの構造物のズレが定量的に解析可能となる．処理手 順を以下に示す。

（1）Fig. 6に示した座標系で，対応する基集点 5 点を用 いて拡大率とフィルム上の照射野位置の違いを求 める。ここで両者には顕著な位置依存性はないと 仮定し，X，Y方向それぞれについて三つの基準点 から最小二乗法を用いて算出する．X方向につい ての拡大率magとフィルム上の照射野位置の違い shiftを(2)〜 (4)式に示す. 式の記号について, Sは シミュレーションイメージ上, Pはポータルイメー ジ上であることを表し，X，YはそれぞれX座標， Y座標を表す。添え字の i にはFig. 6の基準点 1 , 2，Cが含まれる，Y方向についても同様である.

$$
\left(\begin{array}{cc}
\sum S X i^{2} & \sum S X i \\
\sum S X i & N
\end{array}\right)\left(\begin{array}{l}
m a g \\
s h i f t
\end{array}\right)=\left(\begin{array}{c}
\sum S X i \cdot P X i \\
\sum P X i
\end{array}\right)
$$

$$
m a g=\frac{\left|\begin{array}{cc}
\sum S X i \cdot P X i & \sum S X i \\
\sum P X i & N
\end{array}\right|}{\left|\begin{array}{cc}
\sum S X i^{2} & \sum S X i \\
\sum S X i & N
\end{array}\right|}=\frac{\left(\sum S X i \cdot P X i\right) N-\left(\sum S X i\right)\left(\sum P X i\right)}{\left(\sum S X i^{2}\right) N-\left(\sum S X i\right)^{2}}
$$

$$
\text { shift }=\frac{\left|\begin{array}{cc}
\sum S X i^{2} & \sum S X i \cdot P X i \\
\sum S X i & \sum P X i
\end{array}\right|}{\left|\begin{array}{cc}
\sum S X i^{2} & \sum S X i \\
\sum S X i & N
\end{array}\right|}=\frac{\left(\sum S X i^{2}\right)\left(\sum P X i\right)-\left(\sum S X i \cdot P X i\right)\left(\sum S X i\right)}{\left(\sum S X i^{2}\right) N-\left(\sum S X i\right)^{2}}
$$

(2) 求めた拡大率mag_x, mag_yとフィルム上の照射 野位置の違いshift_x, shift_yより, シミュレーシ ヨンイメージまたはポータルイメージのうち画素 サイズが大きい方の画像を線形補間により拡大， 移動し，両画像の照射野を一致させる。

(3) 拡大率の大きさで拡大する画像を変えて処理を分 ける. (a)mag_x, mag_y $>10$ と, シミュレーシ ヨンイメージを拡大する(Fig. 7).（b) mag_x, mag_y<1のとき, ポータルイメージを拡大する (Fig. 8).

\section{2-5 コントラストの改善}

Fig. 3に示したシミュレーションイメージとポータ

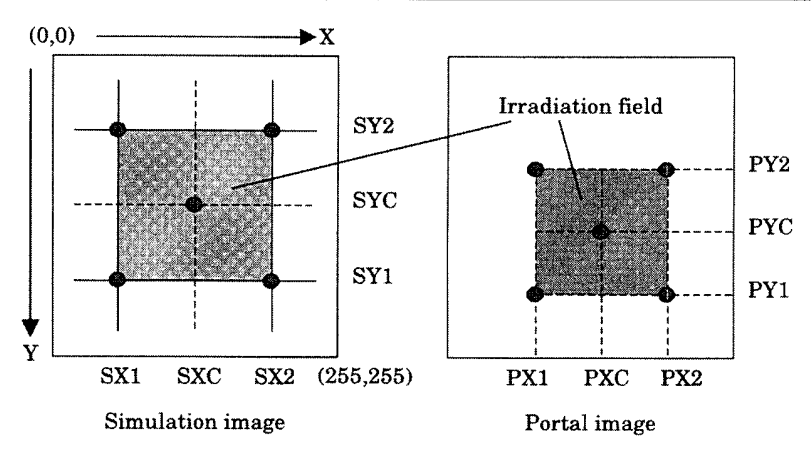

Fig. 6 Coordinate system of a simulation image and portal image.

ルイメージの原画像では, 撮影条件の違い, 特にX 線エネルギーが異なるため両画像のコントラストは大 きく異なっている，両画像間のズレを検出するための 比較対象となる骨陰影は, $70 \mathrm{kVp}$ の線で撮影したシ ミュレーションイメージでは良好に描出されている が，6MVのX線で撮影したポータルイメージでは描出 能が大きく劣っている。 これ以外にも撮影条件の設定 ミスなどのため，コントラストおよびフィルム濃度が 不良になる場合が考えられ，これらの補正が必要とな ってくる.ここでは各画像のヒストグラムからその偏 りを補正(一様化)し，コントラストを強調する手法 (ヒストグラムの平坦化)を用いた。

\section{2-6 骨陰影のエッジ抽出}

コントラスト強調したシミュレーションイメージお よびポータルイメージから, 両画像間のズレを検出す るための比較対象となる骨陰影のエッジを抽出する.

Fig. 9に示したコントラスト強調画像では階調の不連続 な部分が発生しており，このままエッジ強調処理を行 った場合，この部分が線状に残ってしまう可能性があ る.そこで先に移動平均によりスムージング処理を行 った．使用した線形平滑化フィルタを(5)式に示す。

$$
\begin{aligned}
g(x, y)=\frac{1}{9}\{ & f(x-1, y-1)+f(x, y-1)+f(x+1, y-1) \\
& +f(x-1, y)+f(x, y)+f(x+1, y) \\
& +f(x-1, y+1)+f(x, y+1)+f(x+1, y+1)\}
\end{aligned}
$$

ここで座標 $(\mathrm{x}, \mathrm{y})$ における入力画像の画素值を $\mathrm{f}(\mathrm{x}$, $\mathrm{y})$ ，出力画像の画素值を $\mathrm{g}(\mathrm{x}, \mathrm{y})$ とする.

次に 8 近傍に対する 2 次微分処理を行い画像中の 高周波成分を強調し, エッジ部分を抽出する. 二次元 空間における 2 次微分すなわちラプラシアンLおよび ラプラシアンフィルタを(6), (7)式に示す.

$$
L=\frac{\partial^{2}}{\partial x^{2}}+\frac{\partial^{2}}{\partial y^{2}}
$$



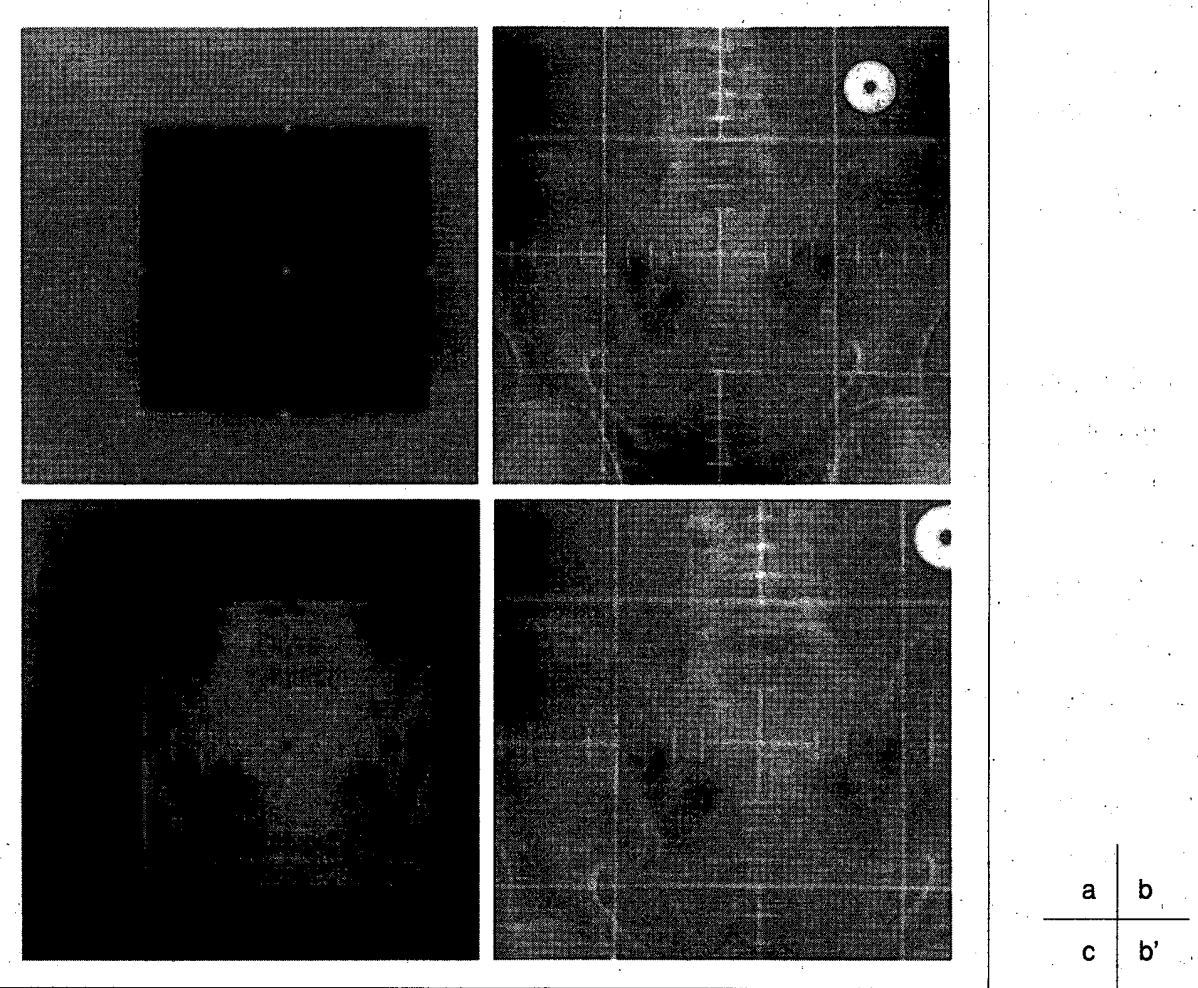

Fig. 7 Result of geometrical transformation in the case of a simulation image that is enlarged and moved.

(a) Original portal image.

(b) Original simulation image.

(b') Simulation image that is enlarged and moved.

(c) Superimposed image of the processed simulation image (b') and original portal image (a).
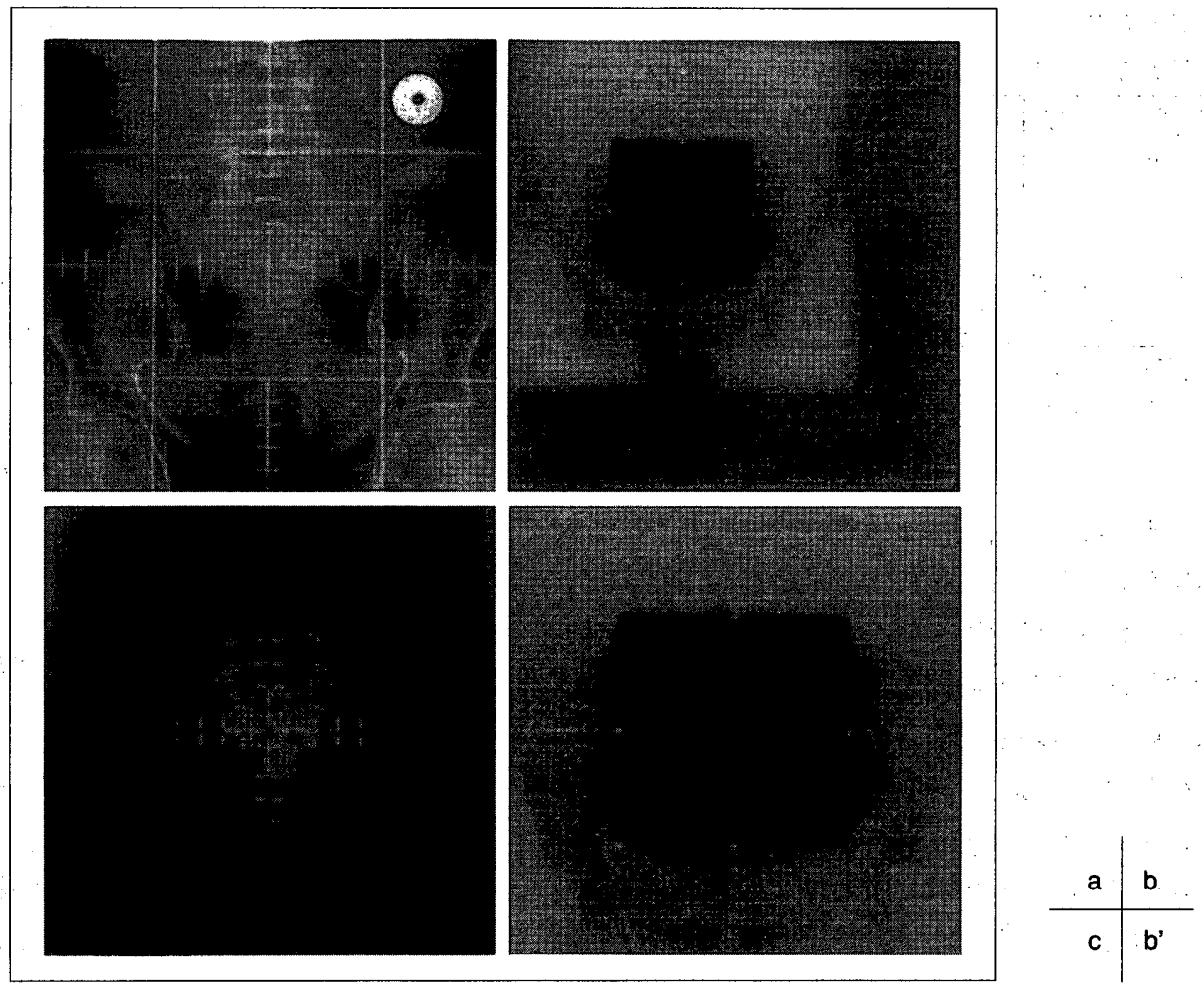

Fig. 8 Result of geometrical transformation in the case of a portal image that is enlarged and moved.

(a) Original simulation image:

(b) Original portal image.

(b') Portal image that is enlarged and moved.

(c) Superimposed image of the processed portal image (b') and original simulation image (a). 


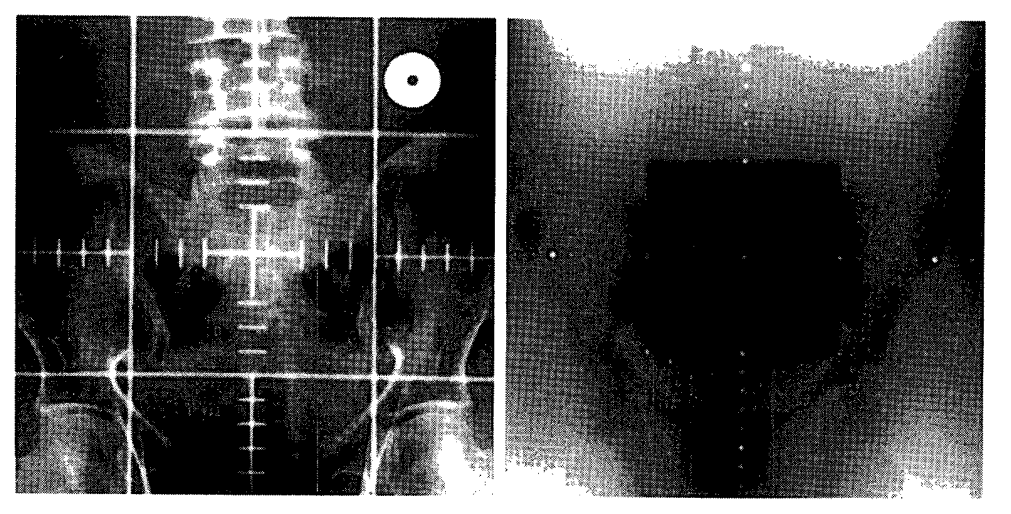

Fig. 9 Effect of contrast enhancement technique.

(a) Simulation image after processing.

(b) Portal image after processing.

$$
\begin{aligned}
g(x, y)= & -f(x-1, y-1)-f(x, y-1)-f(x+1, y-1) \\
& -f(x-1, y)+8 f(x, \mathrm{y})-f(x+1, \mathrm{y}) \\
& -f(x-1, \mathrm{y}+1)-f(x, \mathrm{y}+1)-f(x+1, \mathrm{y}+1)
\end{aligned}
$$

最後に階調画像を 2 值化するにあたり，その間值を 決める必要があるが，ヒストグラムがなだらかに変化 する(山や谷が存在しない)場合，閯値を絶対值として 指定する方法では画像全体の濃淡の影響を大きく受け ると考えられる，そこで，全画素数に対する 2 值化後 の図形画素の割合を指定し 2 值化処理を行う，パーセ ンタイル法を用いた。ささらに両画像上には $1 \mathrm{~cm}$ 間隔の 目盛りが刻まれており，これらが高い相関を示すため シミュレーションイメージ上の目盛り線に相当する部 分を消去した (Fig. 10).

\section{2-7 ズレの方向および大きさの検出}

シミュレーションイメージに対するポータルイメー ジのズレの方向および大きさを検出するため，両画像 間の相互相関関数を求めた。(8)式に連続系, 無限個 のデータ系列による二次元の相互相関関数を示す.

$$
\begin{aligned}
R_{f g}(\kappa, \lambda)= & \lim _{M \rightarrow \infty} \lim _{N \rightarrow \infty} \frac{1}{4 M N} \int_{-M}^{M} \int_{-N}^{N}\{f(m, n) \cdot g(m+\kappa, n+\lambda)\} d m d n \\
& (-\infty \leq \kappa \leq \infty,-\infty \leq \lambda \leq \infty) \cdots \cdots \cdots \cdots \cdots \cdots \cdots(8)
\end{aligned}
$$

ここで, $(8)$ 式の $\kappa, \lambda$ 二つのアナログ画像 $\mathrm{f}(\mathrm{m}, \mathrm{n})$ と $\mathrm{g}(\mathrm{m}, \mathrm{n})$ の間のズレ量を表しており，相互相関値 $\mathrm{R}_{\mathrm{fg}}$ が 最大となる $(\kappa, \lambda)$ が両画像のズレとなる.

これを離散系, 有限個のデー夕系列であるデイジ夕 ル画像 $\mathrm{f}(\mathrm{x}, \mathrm{y}), \mathrm{g}(\mathrm{x}, \mathrm{y}) \quad\{\mathrm{x}=0,1,2, \cdots, \mathrm{Xsize}-1\}$

$\{y=0,1,2, \cdots, Y$ size-1 $\}$ に対応させた二次元の相 互相関関数を(9)式に示す。ただし，Xsize，Ysizeは 画像 $\mathrm{f}, \mathrm{g}$ のマトリックスサイズであり, $0 \leqq \mathrm{x}<\mathrm{Xsize}$,
$0 \leqq y<Y \operatorname{size}$ の範囲外では $\mathrm{f}(\mathrm{x}, \mathrm{y})=\mathrm{g}(\mathrm{x}, \mathrm{y})=0$ と仮定す る.

$$
\begin{aligned}
& R_{x y}(k, l)=\frac{1}{(X \text { size }-|k|)(Y \text { size }-|l|)} \sum_{x=0}^{X \text { Xsize }-1} \sum_{y=0} \sum_{\text {size }-1}\{f(x, y) \cdot g(x+k, y+l)\} \\
& (k=- \text { Xsize } / 2, \cdots, 0, \cdots, \text { Xsize } / 2 \quad l=-Y \text { size } / 2, \cdots, 0, \cdots, Y \text { size } / 2)
\end{aligned}
$$

ここで，(9)式の k, l は二つのディジタル画像 $\mathrm{f}(\mathrm{x}, \mathrm{y})$ と $\mathrm{g}(\mathrm{x}, \mathrm{y})$ の間のズレ量を表しており，相互相関值 $\mathrm{R}_{\mathrm{xy}}$ が最大となる $(\mathrm{k}, 1)$ が画画像のズレとなる.

\section{3. 結 果}

基潐点の検出 (2-3節) $\mathrm{p}$ および拡大率とフィルム位置 の補正(2-4節)の処理結果をFig. 7，8に示す. Fig. 7b, 8bを拡大，移動処理した結果がFig. 7b’，8b’である. 画素サイズはFig. 7a，8aと同じになる．両者を重ね合 わせた画像がFig. 7c，8cで，シミュレーションイメー ジの照射野とポータルイメージの照射野が一致してい るのが確認できる。

コントラストの改善(2-5節)の処理結果をFig. 9に示 す. 原画像 (Fig. 3) と比較してコントラストが強調さ れたことが確認できる。

骨院影のエッジ抽出(2-6節)の処理結果をFig. 10に 示す．ここまでの処理で, シミュレーションイメージ とポータルイメージの拡大率，つまり画素サイズが同 じとなり，画像上の照射野位置が一致した。さらにこ の状態で両画像に含まれる骨陰影のエッジ部分が抽出 されていることが確認できる.

ズレの方向および大きさの検出 (2-7節)の処理結果 をFig. 11に示す。この例では, ポータルイメージの骨 陰影がシミュレーションイメージのそれに対して，画 像上で左に 8pixel, 上に6pixelずれていると検出し た.すなわち既知のズレ量がX，Y方向ともに $5.0 \mathrm{~mm}$ であるのに対して，本手法ではX方向に $6.2 \mathrm{~mm}, \mathrm{Y}$ 方 

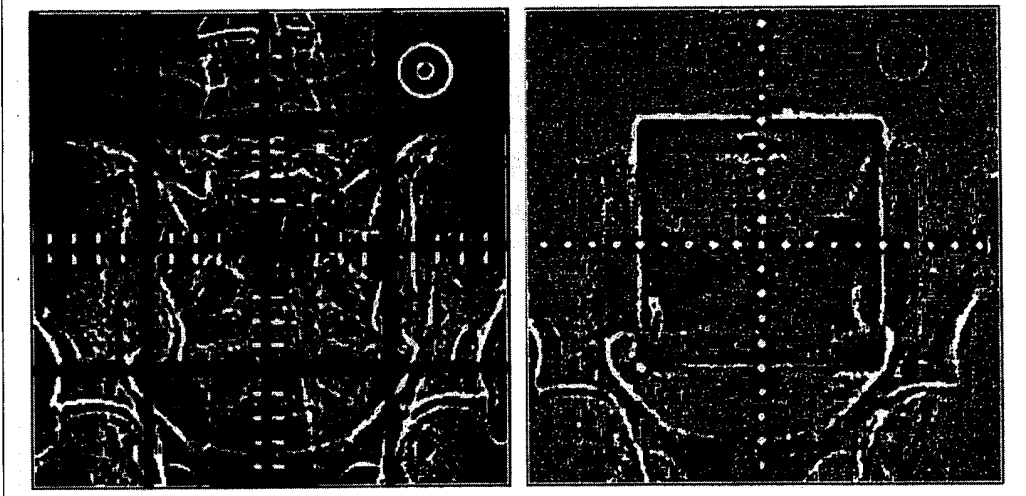

Fig. 10 Effect of edge extraction technique.

(a) Simulation image after processing.

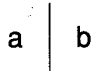

(b) Portal image after processing.

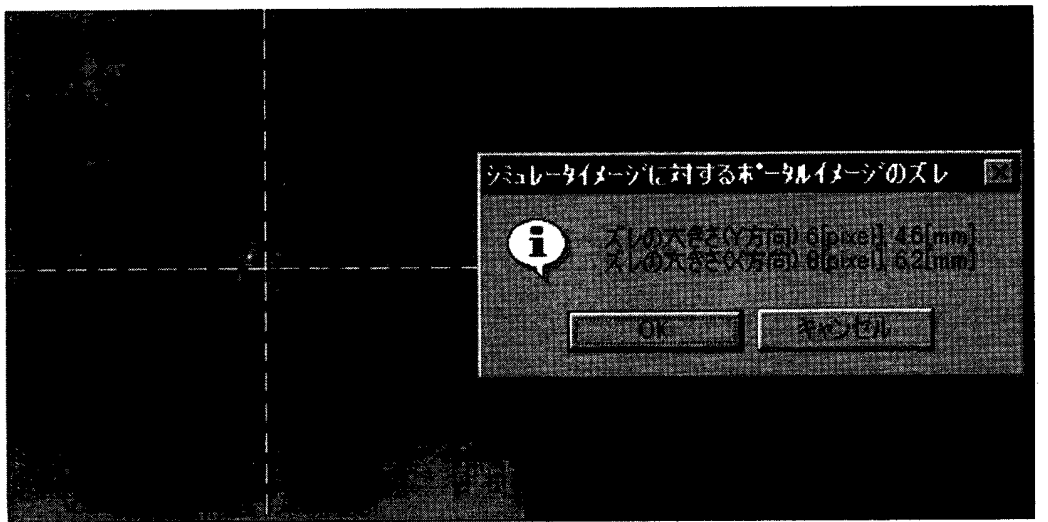

Fig. 11 Calculated values of a two-dimensional cross-correlation function.

向に4.6mmずれていると検出した.

本手法の有用性を評価するため，1-2節に示した 84 対のシミュレーションイメージとポータルイメージを 用いて処理を行った。横軸に既知のズレ量と検出值の 差(誤検出量)を, 縦軸に頻度を示した結果をFig. 12に 示す.ズレの大きさについて, 誤検出量の絶対值とし て, 平均 $0.9 \mathrm{~mm}$, 標準偏差 $0.8 \mathrm{~mm}$, 最大 $2.7 \mathrm{~mm}$ の誤 りで検出できた。またFig. 13より既知のズレ量が $0.0 \mathrm{~mm}$ の場合では，同 $5.0 \mathrm{~mm}$ と $10.0 \mathrm{~mm}$ の場合と比べ て，その平均誤検出量が有意に小さくなった.

\section{4. 登 案}

シミミレーションイメージとポータルイメージでは 撮影に用いるX線エネルギーが異なるため, 被写体コ ントラストが大幅に異なっている。 シミュレーション イメージでは約70kVpくらいであり光電効果が支配的 となるため，被写体コントラストは原子番号による影 響を大きく受ける。しかしポータルイメージでは約 6MVでありコンプトン効果が支配的となるため，被 写体コントラストは密度による影響を大きく受ける。
一般に両画像の比較は目視で行われており, 主に被写 体コントラストの違いに起因する画像コントラストの 違いが両画像の比較を困難なものとしている. 本手法 では両画像に対してヒストグラムの平坦化処理を行う ことで，人為的なパラメータを用いずに画像コントラ ストが強調できたと考える：2 值化処理では，対象と する部位が同じ場合では画像中に含まれる骨陰影など の割合も似たような值となるため, パーセンタイル法 により間接的に閾值を決定する方が被写体の影響 (個 体差)を受けにくいと考えられる，逆に対象部位が異 なる場合では; 画像に含まれる骨陰影の割合が変わっ てしまうため, パーセンタイル法で指定する図形画素 の割合を見直す必要があり, 今後の課題である。

また，X線フィルムをディジタル化する過程で画素 サイズが決まるが，本手法では照射野サイズと基準点 の座標より画素サイズを計算している.ここで，外部 放射線治療装置の精度管理に関するガイドライン7)に よると.，X線照射野の許容誤差は，その大きさが $20 \mathrm{~cm} \times 20 \mathrm{~cm}$ よりさい場合では, $\pm 2 \mathrm{~mm}$ となってい る.. 本手法の有用性の検討で用いた照射野サイズは最 


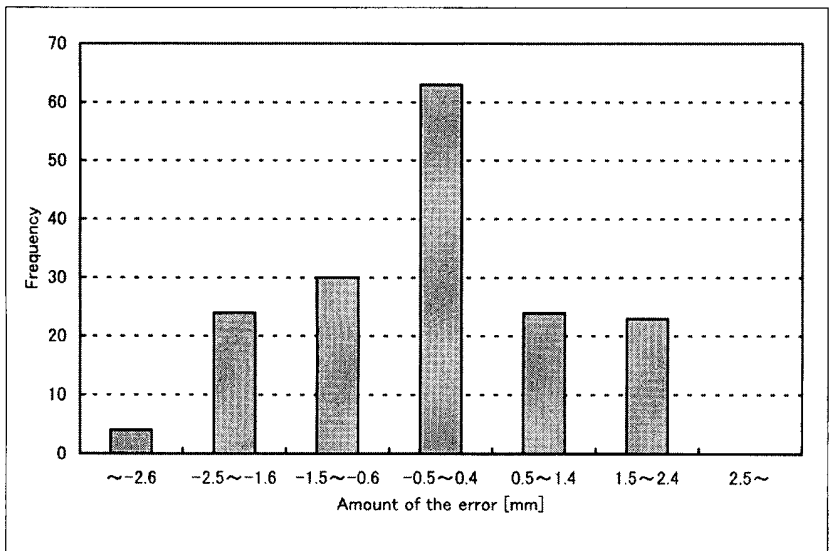

Fig. 12 Results of this method in 84 pairs of simulation images and portal images.

小 $5 \mathrm{~cm} \times 5 \mathrm{~cm}$ であり，このときの誤差率が最も大き く, $4 \%$ となる. 本手法では, ズレの大きさは画素数 として検出し，これに画素サイズを乗じて実寸に変換 している，そのためズレが大きい場合では，計算した 画素サイズに含まれる誤差が，ズレとして検出した画 素数倍されることによって，Fig. 13に示すように誤検 出量が大きくなったと考えられる，さらに，最終的な 精度や検出限界は，画素サイズに大きく依存するた め, 目標值より十分に小さい画素サイズでディジタル 化する必要がある，今回，画素サイズは $0.8 \mathrm{~mm}$ 程度で あり，その結果は誤検出量の平均值 $+1 \mathrm{SD} て ゙ 1.7 \mathrm{~mm}$ と なった。この結果はAAPMレポートTG4087に示された 患者位置決誤差 $5 \mathrm{~mm}$ 以内という報告より小さく， シミュレーションイメージとポータルイメージのズレ

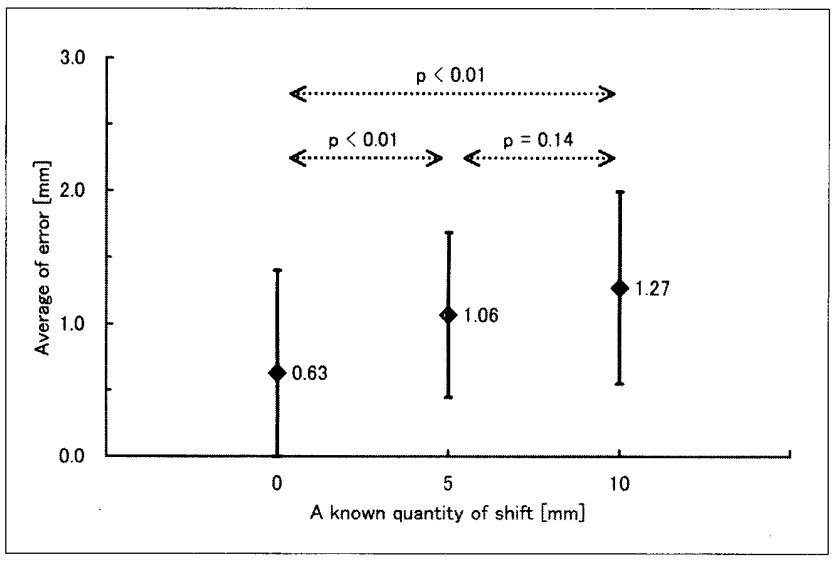

Fig. 13 Results classified according to the known quantity of shift.

の検出に使用可能と考える.

\section{5. 結 語}

シミュレーションイメージとポータルイメージの間 のズレを，コンピュータを用いた画像処理により客観 的かつ定量的に検出する方法を開発した。骨盤部人体 ファントムを用い有用性を検討した結果，平均 $0.9 \mathrm{~mm}$ の誤りで検出できた。また本手法では人為的なパラメ ータを必要としないため, 処理の自動化が可能であ る.

\section{謝 辞}

本研究について，有益な助言をくださいました京都大 学医学部附属病院放射線部の皆様に感謝いたします。

\section{参考文献}

1) 村山重行：放射線治療の照合システム。INNERVISION, 12(10), 89-91，(1997).

2) 工藤牧男, 植田俊男, 室加 守：放射線治療における照射 位置の再現性に関する検討。日放技学誌，33(3)，250255, (1977).

3）井澤一雄, 秦潔, 佐々木潤一, 他: X線外部照射における 照射位置の再現性について。日放技学誌，41(2)，271278 , (1985).

4) 井ノ上信一, 松本光弘, 長谷川浩典, 他：放射線治療に扮 けるelectronic portal imaging devices (EPID)を用いた照合
画像の解析. 日放技学誌，55(5)，500-506，(1999).

5) 井上誠喜, 八木伸行, 林 正樹, 他：C言語で学ぶ実践画 像処理. オーム社, 初版, (1999).

6) 安居院猛, 長尾智晴：C言語による画像処理入門. 昭晃 堂, 初版, (2000).

7) 日本放射線腫瘍学会研究調查委員会：外部放射線治療装置 の保守管理プログラム，通商産業研究社, 初版, (1992).

8) Kutcher GJ, Coia L, Gillin M, et al.: Comprehensive QA for radiation oncology: Report of AAPM Radiation Therapy Committee Task Group 40. Med Phys, 21, 518-618,(1994). 


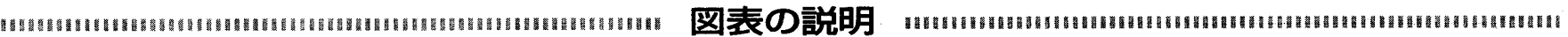

Fig. 1 すべてのシミュレージョンイメージ

上段より，アイソセンタが仙骨中央部，腸骨部，股関節部の 3 種類. 左列より，照射野サイズが $5 \mathrm{~cm} \times 5 \mathrm{~cm}, 10 \mathrm{~cm} \times 10 \mathrm{~cm}$, $15 \mathrm{~cm} \times 15 \mathrm{~cm}$, 頭尾方向 $14 \mathrm{~cm}$ 非対称 $\times$ 左右方向 $8 \mathrm{~cm}$ 非対称の 4 種類.

Fig. 2 画像処理の概略

Fig. 3 シミュレーションイメージとポータルイメージの原画像

図中の丸印は五つの基準点を表す。

(a) シミュレーションイメージの原画像

(b) ポータルイメージの原画像

Fig. 4 基準点の検出(シミュレーションイメージ)
(a) 原画像
(b)Y方向のプロファイルから抽出したピーク
(c)X方向のプロファイルから抽出したピーク
(d)X方向およびY方向の平均画素值のプロファイル

Fig. 5 基準点の検出 (ポータルイメージ)
(a) 原画像
(b)Y方向のプロファイルから抽出したピーク
(c) X方向のプロファイルから抽出したピーク
(d) X方向およびY方向の平均画素値のプロファイル

Fig. 6 シミュレーションイメージとポータルイメージの座標系

Fig. 7 幾何学変換処理(シミュレーションイメージを拡大する場合)
(a) ポータルイメージの原画像
(b)シミュレーションイメージの原画像
(b')拡大，移動処理したシミュレーションイメージ
(c) 拡大, 移動処理したシミュレーションイメージ(b') とポータルイメージの原画像(a)の重ね合わせ

Fig. 8 ．幾何学変換処理 (ポータルイメージを拡大する場合)
(a)シミュレーションイメージの原画像
(b) ポータルイメージの原画像
(b') 拡大, 移動処理したポータルイメージ
(c) 拡大, 移動処理したポータルイメージ (b') とシミュレーションイメージの原画像(a)の重ね合わせ

Fig. 9 コントラスト強調処理画像
(a) 処理後のシミュレーションイメージ
(b) 処理後のポータルイメージ

Fig. 10 エッジ抽出処理画像
(a) 処理後のシミュレーションイメージ
(b) 処理後のポータルイメージ

Fig. 11 二次元の相互相関関数

Fig. 12 84対のシミュレーションイメージとポータルイメージの処理結果

Fig. 13 ズレの既知量別の処理結果 